\title{
USE OF INFORMATION TECHNOLOGIES IN THE FORMATION OF FOREIGN LANGUAGE COMMUNICATIVE COMPETENCE
}

\author{
USO DE TECNOLOGIAS DE INFORMAÇÃO NA FORMAÇÃO DE COMPETÊNCIA \\ COMUNICATIVA DE LÍNGUA ESTRANGEIRA
}

\author{
USO DE TECNOLOGÍAS DE LA INFORMACIÓN EN LAFORMACIÓN DE \\ COMPETENCIAS COMUNICATIVAS EN LENGUA EXTRANJERA
}

\author{
Oksana Vladimirovna SHEMSHURENKO ${ }^{1}$ \\ Gulnara Ilsurovna NAZAROVA ${ }^{2}$ \\ Liliya Rafhatovna NIZAMIEVA ${ }^{3}$ \\ Elena Rafaelevna PORSHNEVA ${ }^{4}$
}

\begin{abstract}
This article is devoted to didactic and methodological aspects of using information technologies for the development of foreign language communicative competence and assessing the degree of its formation among students. The aim of the study was to determine the didactic conditions for the use of the video conferencing mode as one of the methodological tools to improve the effectiveness of teaching foreign languages at the university, organized both in full-time and in distance. The main empirical research method was experimental training, the evaluation of the results of which was carried out on the basis of specially developed criteria. The study showed that the high didactic potential of this type of modern information technology, such as video conferences with native speakers of a foreign language, which can be realized with competent methodological support, including preliminary planning, preparation and thorough study of all aspects and stages of the lesson. At the same time, the directing and coordinating activity of a teacher who acts as a moderator of educational activities in the lesson is necessary. Assessment of students' speech skills should be conducted in accordance with clear criteria. Subject to the identified didactic conditions, the educational process is enriched with new organizational forms, cognitive independence of students is developing, cognitive interest is stimulated, and positive motivation for learning a foreign language is increased.
\end{abstract}

KEYWORDS: Information technology. Video conference. Distance learning. Interactive educational environment. Interactive cooperation. Communicative competence. Foreign languages.

${ }^{1}$ Kazan Federal University (KPFU), Kazan - Russia. Senior Lecturer of the Department of Theory and Practice of Teaching Foreign Languages, Institute of Philology and Intercultural Communication. Candidate of Philological Sciences. ORCID: https://orcid.org/0000-0002-0987-6223. E-mail: oksanashemshurenko@gmail.com

${ }^{2}$ Kazan Federal University (KPFU), Kazan - Russia. Associate Professor of the Department of Theory and Practice of Teaching Foreign Languages, Institute of Philology and Intercultural Communication. Candidate of Pedagogical Sciences. ORCID: https://orcid.org/0000-0001-7625-4291. E-mail: gulnazar@yandex.ru

${ }^{3}$ Kazan Federal University (KPFU), Kazan - Russia. Associate Professor of the Department of Theory and Practice of Teaching Foreign Languages, Institute of Philology and Intercultural Communication. Candidate of Pedagogical Sciences. ORCID: https://orcid.org/0000-0002-0913-8589. E-mail: lilianiz@yandex.ru

${ }^{4}$ Nizhny Novgorod State Linguistic University (LUNN), Nizhny Novgorod - Russia. Professor of the Department of Theory and Practice of the French Language and Translation, Faculty of Translation and Interpretation. Doctor of Pedagogical Sciences. ORCID: https://orcid.org/0000-0002-5940-0442. E-mail: erp@lunn.ru

Rev. EntreLínguas, Araraquara, v. 7, n. esp. 1, p. 213-222, fev. 2021

e-ISSN: $2447-3529$ 
RESUMO: Este artigo se dedica aos aspectos didáticos e metodológicos do uso das tecnologias da informação para o desenvolvimento da competência comunicativa em língua estrangeira e avalia o grau de sua formação entre os alunos. O objetivo do estudo foi determinar as condições didáticas para a utilização da modalidade de videoconferência como uma das ferramentas metodológicas para melhorar a eficácia do ensino de línguas estrangeiras em uma universidade, organizado em tempo integral e a distância. O principal método de pesquisa empírica foi o treinamento experimental, cuja avaliação dos resultados foi realizada com base em critérios especialmente desenvolvidos. O estudo mostrou que o alto potencial didático desse tipo de tecnologia da informação moderna, como a videoconferência com falantes nativos de uma língua estrangeira, pode ser realizado com um suporte metodológico competente, incluindo planejamento preliminar, preparação e estudo aprofundado de todos os aspectos e etapas a lição. Ao mesmo tempo, é necessária uma atividade de direção e coordenação de um professor que atue como moderador das atividades pedagógicas da aula. A avaliação das habilidades de fala dos alunos deve ser conduzida de acordo com critérios claros. Sujeito às condições didáticas identificadas, o processo educacional é enriquecido com novas formas organizacionais, a independência cognitiva dos alunos está se desenvolvendo, o interesse cognitivo é estimulado e a motivação positiva para aprender uma língua estrangeira é aumentada.

$\boldsymbol{P A L A V R A S - C H A V E : ~ T e c n o l o g i a ~ d a ~ i n f o r m a c ̧ a ̃ o . ~ V i d e o c o n f e r e ̂ n c i a . ~ E d u c a c ̧ a ̃ o ~ a ~ d i s t a ̂ n c i a . ~}$ Ambiente educacional interativo. Cooperação interativa. Competência comunicativa. Linguas estrangeiras.

RESUMEN: Este artículo está dedicado a los aspectos didácticos y metodológicos del uso de las tecnologías de la información para el desarrollo de la competencia comunicativa en lenguas extranjeras y la evaluación del grado de formación de los estudiantes. El objetivo del estudio fue determinar las condiciones didácticas para el uso de la modalidad de videoconferencia como una de las herramientas metodológicas para mejorar la efectividad de la enseñanza de lenguas extranjeras en una universidad, organizada tanto a tiempo completo como a distancia. El principal método de investigación empírica fue la formación experimental, cuya evaluación de los resultados se llevó a cabo sobre la base de criterios especialmente desarrollados. El estudio mostró que el alto potencial lingüístico de este tipo de tecnología de la información moderna, como la videoconferencia con hablantes nativos de una lengua extranjera, se puede realizar con un apoyo metodológico competente, incluida la planificación preliminar, la preparación y el estudio exhaustivo de todos los aspectos y etapas del proceso. la leccion. Al mismo tiempo, es necesaria una actividad de dirección y coordinación de un profesor que actúe como moderador de las actividades educativas en la lección. La evaluación de las habilidades del habla de los estudiantes debe realizarse de acuerdo con criterios claros. Sujeto a las condiciones didácticas identificadas, el proceso educativo se enriquece con nuevas formas organizativas, se desarrolla la independencia cognitiva de los estudiantes, se estimula el interés cognitivo y se incrementa la motivación positiva para el aprendizaje de una lengua extranjera.

PALABRAS CLAVE: Tecnología de la información. Videoconferência. Educación a distancia. Entorno educativo interactivo. Cooperación interactiva. Competencia comunicativa. Lenguas extranjeras. 


\section{Introduction}

Currently, due to the risk of various emergencies, training at all levels should be ready at any time to switch to a distanced format, without losing its effectiveness, which can be achieved through the use of modern information technologies. It should be noted that distance learning can adequately compete with traditional full-time forms of education, while having certain advantages that need to be actively introduced into the educational process.

Under the term "distance learning" we understand a technology for organizing the educational process, which is carried out mainly with the use of information and telecommunication technologies in the interactive cooperation of remote participants through open access channels (mainly via the Internet). Modern means of communication facilitate the establishment of remote contact between participants in the educational process, and joint telecommunication projects help to reveal the abilities of students, avoiding the shortcomings of traditional group work and guaranteeing individualization of training (ABDULLINA et al., 2017).

Nowadays, information technologies are widely used in the practice of teaching foreign languages, allowing more an efficient organization the educational process, improving the foreign language communicative competence of students, developing their cognitive independence, as well as providing distance learning (LI; IRBY, 2008; SHARIPOVA et al., 2017, MARTIN, 2009). We consider communicative competence as the ability to carry out speech activity by means of the studied language in accordance with the goals and situation of communication within the framework of a particular field of activity (NAZAROVA et al., 2019). The basis of communicative competence is language knowledge, speech skills and abilities, as well as the potential of the individual to independently improve the formed communicative skills (MAMAEVA; VASSILIEVA; GALEEVA, 2018).

The practice-oriented model of education defines foreign-language communicative competence not only as the sum of knowledge, skills, but also as the individual's ability to actualize the potential acquired in the learning process (FAHRUTDINOVA; FAHRUTDINOV; YUSUPOV, 2016; VASSILIEVA; KUZMINA, 2018). Thus, the very concept of "competence" in the framework of foreign language communicative competence is interpreted as a structure that reflects the interaction of cognitive and effective skills, the presence of motivation and relevant value orientations. In other words, the components of communicative competence are a combination of internal and external aspects of a person's communicative activity. 
At the present stage of the development of education, the effective formation of communicative competence as the goal of teaching foreign languages is achieved through the use of various information technologies, multimedia educational programs, authentic audio and video materials that can solve the problem of lack of speech practice, intensify the educational process and bring it closer to real situations of foreign language communication.

\section{Methods}

The effectiveness of using audio and video materials in the educational process is undeniable, but they allow students to act mainly as recipients of the foreign language speech, although they allow the creation of a speech situation in the classroom. However, the educational speech situation cannot completely replace the real communication situation. Therefore, in our opinion, one of the most effective ways of organizing the process of teaching a foreign language using information technology is to use the video conference mode with native speakers of the studied language.

Video conference is an area of information technology that provides simultaneous twoway transmission of interactive information at a distance in real time. Video conference allows you to organize a conversation of two or more persons, whose participants are removed from each other and communicate using webcams. Video conference with native speakers allows you to develop the spontaneity of foreign speech, teaches you to recognize non-verbal means of communication such as facial expressions and gestures, introduces you to the culture of communication and the style of relationships in the country of the language being studied. It refers to such information technologies that create a virtual linguistic and cultural space, facilitate the exchange between representatives of different linguistic societies.

Considering the linguodidactic potential of video conference, it should be noted that it enables virtual immersion in an authentic environment of the functioning of the language and culture, interactive cooperation with their real speakers, creating the conditions for a foreign language polylogue (VARLAMOVA; BOCHINA; MIFTAKHOVA, 2016). Individualization is of particular importance in improving the various components of communicative competence, because, depending on the personally significant topics of the trainees and the purpose of the lesson, the student-linguist conducts a conversation with native speakers of the language he is studying, aimed at improving whether his linguistic, sociolinguistic, cultural or linguistic and speech competence. 
The aim of the study was to determine the didactic conditions for the use of the video conference mode as one of the methodological tools for the formation of communicative competence of students, as well as to identify the effectiveness of the considered form of interactive cooperation in the process of teaching foreign languages.

The main empirical method of research was the experimental teaching of the French language using the video conferencing mode, conducted by us on the basis of the Kazan Federal University. The topics of video conference are the problems of modern youth. Learning outcomes were evaluated based on specially designed criteria. An analysis of organized learning allowed us to draw conclusions about its effectiveness and justify didactic conditions, the observance of which allows us to use the considered variety of information technologies as a means of forming the communicative competence of students with full-time and distance learning of foreign languages.

\section{Results and discussion}

The availability of a computer class with Internet access and equipping computers with a webcam and microphone is the necessary equipment for a classroom work. Among a wide range of software, one of the most affordable one is Skype (KHASANOVA; SHEMSHURENKO; KARIMOVA, 2016). Video communication can be organized with various native speakers, but the most effective, in our opinion, is the organization of joint classes with foreign teachers and peers of students, which allows us to solve a wider range of didactic tasks. We offer a description of one of our classes with the participation of French speakers, which was organized by video conference.

Before the lesson, the students repeated the thematic vocabulary under the guidance of a teacher who, if necessary, introduced the unknown lexical units to them. It is important to set up students for active communication, motivate them to ask questions, offer their own solutions to the problems discussed. It will be useful to recall the etiquette of speech behavior.

The lesson began with a presentation by the video conference participants, followed by a small monologue of the francophone participant, during which he briefly covered the conversation. Such preliminary listening is designed to help tune into the process of perceiving the speech of native speakers, since the teacher, as a rule, has a clearer and more measured pronunciation and less abuse of colloquial expressions and jargon, characteristic of young people. Speech of a native speaker may initially be much more difficult to understand due to the above reasons. This fact once again confirms the value of these types of activities, as they 
provide an opportunity to learn a lively modern language of communication, and not only master its literary form.

Then, individual mini-conversations (for two to three minutes) were organized for each student with native French speakers. During this conversation, questions were asked regarding the topic of the lesson.

At the next stage of the lesson, the initiative was provided by the trainees themselves, who were able to discuss various aspects of the problem under consideration. The discussion can be organized in the format of a "round table", where students take turns have the right to speak and ask questions of interest.

At the end of the lesson summarizing the discussion topic. Each student had the opportunity to express their opinion and state their point of view on the issue under consideration.

A foreign language teacher can take a minimal part in the conversation, but must constantly monitor students' attention and maintain their activity. At the same time, he has the opportunity to evaluate the student's speech skills by certain parameters. Among the main parameters for assessing the skills of verbal communication in French during the testing process, we used the following criteria: normative pronunciation, active participation in the dialogue, knowledge of vocabulary and topical information, the formation of morphological and syntactic skills.

Let us consider in details the criteria for assessing foreign communicative competence used during the research.

1. Normative pronunciation. The pace of speech, the presence or absence of unreasonable pauses, the adequacy of the melody of phrases to a speech task are evaluated.

2. Active participation in the dialogue. It assesses the presence of interest in the conversation and in the interlocutor, the breadth of answers, the number of initiative remarks, the incitement of the interlocutor to continue the conversation, the ability to ask questions and counter-questions, the ability to develop and clarify one's thoughts and beliefs, to defend the chosen point of view with due consideration, taking into account the objections expressed by the interlocutor.

3. Possession of vocabulary and subject information. When assessing, the volume of the learner's lexical stock, the ability to speak on the proposed topic, clearly expressing one's thoughts and avoiding unjustified repetitions, the use of lexical units in their exact meaning, the ability to use paraphrasing techniques to fill in situational lexical gaps, are taken into account. 
4. The formation of morphological and syntactic skills. The ability to use complex grammatical structures is evaluated; correctness in the use of verb tenses, pronouns, determinatives, all kinds of approvals, connectors; the ability to build various forms of simple and complex sentences; the presence or absence of grammatical errors that impede the act of communication.

The work of the students was evaluated in accordance with the developed criteria. Testing showed that video conference solves one of the main problems of the process of forming foreign language communicative competence, i.e. the lack of direct communication with native speakers at school and, often, at the University. The fact that in the process of video conference students cannot only hear the interlocutor's voice, but also can watch him, facilitates understanding of his speech and, as a result, increases the effectiveness of listening. Communication with francophones helps to remove psychological barriers in the implementation of the speaking process, and the possibility of using non-verbal means of communication favors mutual understanding. All this provides an increase in the effectiveness of the formation of communicative competence of students.

The didactic conditions were determined basing on the results of the experimental training. The observance of these conditions is necessary for the successful implementation of video conference as a form of interactive cooperation.

A necessary condition, in addition to the technical equipment of the office, is to establish contacts with interested foreign colleagues. This will allow conducting joint classes in the mode of video conference with foreign students. The teacher should discuss the topic of the lesson in advance and draw up his plan. The removal of psychological difficulties will be facilitated by the choice of a topic that is familiar to students and equally interesting to both sides of communication. Therefore, such a lesson is easier to conduct as a final lesson on the topic.

Considering all these didactic conditions, the use of the video conference mode contributes to the effective formation of foreign language communicative competence of students.

\section{Summary}

The realities of the modern information society require an individual learning a foreign language to be prepared and able to carry out interpersonal and intercultural communication. However, mastering a foreign language of oral and written speech in a general educational 
institution is faced with the impossibility of its use in direct communication with native speakers of the language being studied. Overcoming this problem becomes possible due to the creation of an interactive educational environment that provides live situational interaction in a foreign language.

An important advantage of the area of information technology that we have examined is that video communication can be used by students in the process of extracurricular activities, thereby increasing their cognitive independence, which is of particular importance at the present stage of higher education, when more and more attention is paid to students' independent work (DEJEAN; MANGENOT; SOUBRIE, 2011). After students establish personal contacts with foreign students, the teacher will offer assignments for independent discussion with their French-speaking peers. As a result of such discussions, students can, for example, be invited to write an essay on the discussed topics, which will allow the teacher to evaluate their skills in a written discourse. Together with foreign peers, topical reports can be prepared both for presentation and discussion in the classroom, and for participating in student conferences, which can also be held online.

Thus, interactive cooperation activates the emotional sphere of students, mobilizes their knowledge, skills and abilities, increases cognitive interest and motivation.

\section{Conclusions}

Language is a permanently changing structure, therefore, the forms of its study and control must be simultaneously and timely transformed. At the present stage of technical development, more and more opportunities are opening up for improving the process of forming foreign-language communicative competence and revealing the level of its formation.

The interactive educational environment has several advantages due to its dialogical nature, activity-creative nature, providing the possibility of independent decision-making, support for individual development and cooperation. Interactive cooperation of participants in the educational process should be built taking into account individual characteristics, needs and motives of students, based on mutual understanding and the development of empathy. This will ensure the creation of comfortable conditions for mastering a foreign language, in which students will feel their success and intellectual viability.

In general, innovative information technologies make it possible to ensure that the language and speech training of students is consistent with the social order of society for a comprehensively developed person with sociocultural, intercultural, linguistic and speech 
competencies. New forms of organization of the educational process contribute to its intensification by stimulating cognitive activity, which ultimately leads to increased learning efficiency.

ACKNOWLEDGEMENTS: The work is performed according to the Russian Government Program of Competitive Growth of Kazan Federal University.

\section{REFERENCES}

ABDULLINA, L. R. et al. The information educational technologies in the development of students' cognitive self-study and practical autonomy. Ad Alta-Journal of Interdisciplinary Research, v. 7, n. 2, p. 81-83, 2017.

DEJEAN, C.; MANGENOT, F.; SOUBRIE, T. Apprentissages formels et informels, autonomie et guidage. Actes du colloque EPAL 2011, Université Stendhal, p. 9-15, 2011.

FAHRUTDINOVA, R. A.; FAHRUTDINOV, R. R.; YUSUPOV, R. N. The Model of forming communicative competence of students in the process of teaching the English language. International Journal of Environmental \& Science Education, v.11, n. 6, p. 1285-1294, 2016.

KHASANOVA, O.; SHEMSHURENKO, O.; KARIMOVA, A. Skype technology in developing speaking skills in teaching ESL. 2016.

LI, C.; IRBY, B. An overview of online education: Attractiveness, benefits, challenges, concerns and recommendations. College Student Journal, v. 49, n. 2, p. 449-458, 2008.

MAMAEVA, A. D.; VASSILIEVA, V. N.; GALEEVA, G. I. The Experimental Research of Techno-R Technology in Teaching the Aspect of speaking a Foreign Language as a type of Vocal Activity. Revista Publicando, v. 4, n. 13, p. 517-525, 2018.

MARTIN, J. Developing course material for online adult instruction. Journal of Online Learning, v.5, n. 2, p. 364-371, 2009.

NAZAROVA, G. I. et al. Designing The Technologies of Teaching Written Business Communication in the French Language For Universities. Revista TURISMO: Estudos e Práticas, v. 2, 2019.

SHARIPOVA, D. Y. et al. Improving the quality of professional training of students in the distance learning. Man in India, v. 97, n.3, p. 401-416, 2017.

VARLAMOVA, M. Y.; BOCHINA, T. G.; MIFTAKHOVA, A. N. Interactivity in teaching a foreign language. J. Lang. Lit, v. 7, n. 3, p. 190-194, 2016. 
VASSILIEVA, V. N.; KUZMINA, E. K. Capabilities of Techno-R Technology in The Improvement if Education Quality in The Field of Teaching Foreign Languages. Modern Journal of Language Teaching Methods, v. 8, n. 11, p. 259-264, 2018.

\section{How to reference this article}

SHEMSHURENKO, O. V.; NAZAROVA, G. I.; NIZAMIEVA, L. R.; PORSHNEVA, E. R. Use of information technologies in the formation of foreign language communicative competence. Rev. EntreLínguas, Araraquara, v. 7, n. esp. 1, p. 213-222, fev. 2021. e-ISSN: 2447-3529. DOI: https://doi.org/10.29051/el.v7iEsp1.14890

Submitted: $28 / 10 / 2020$

Required revisions: 19/12/2020

Approved: 13/01/2021

Published: 28/02/2021 